УДК 373.2.011.3-051

DOI: 10.35619 /iiu.v1i10.202

\author{
Дичківська Ілона \\ доктор педагогічних наук, професор, завідувачка \\ кафедри педагогіки і психології \\ (дошкільної та корекційної) \\ імені проф. Т. І. Поніманської \\ Рівненського державного гуманітарного університету, \\ м. Рівне, Україна \\ ORCID:0000-0002-9353-5666 \\ e-mail: ilonardgu@gmail.com
}

\title{
МЕТОДОЛОГІЧНІ ПІДХОДИ У ПОБУДОВІ СИСТЕМИ ВИМОГ ДО СУЧАСНОГО ФАХІВЦЯ ДОШКІЛЬНОЇ ОСВІТИ
}

\begin{abstract}
Анотація. У статті проаналізовано зміну стратегії підготовки сучасних фахівців, зокрема вихователів дошкільних закладів, в умовах інноваційної трансформації освіти, схарактеризовано поняття «інноваційна спрямованість вихователя», «готовність до інноваційної діяльності», «інноваційна культура», «інноваційна компетентність» та встановлено зв'язки між ними. Аналіз підходів різних авторів засвідчує, що одностайності у підходах до розуміння їх суті у дослідників немає. Однак науковці відзначають важливість ролі педагога у здійсненні інноваційних процесів, що актуалізує проблему розуміння вимог до нього. У статті обгрунтовано та розроблено комплекс вимог до вихователів у контексті реалізації інновацій у дошкільній освіті в площині трьох підходів: особистісного (наявність інноваційної спрямованості, сформованість інноваційної культури), діяльнісного (володіння технологіями дослідницької й проектної роботи, прийняття суб'єктності дитини як цінності, здатність до взаємодії 3 іншими педагогами) та компетентнісного (оволодіння інноваційною компетентністю). Аналізуючи вимоги до рівня теоретичних знань і практичної підготовки вихователя, наголошується, на умінні спрямовувати навчальновиховний процес на особистість вихованця, вибудовуванні своєї професійної діяльності так, аби кожна дитина мала необмежені можливості для самостійного і високоефективного розвитку. А це у принципово інших вимірах визначає проблематику і зміст професійної та особистісної підготовки вихователя, актуалізує необхідність створення педагогічних систем, зорієнтованих на інноваційну діяльність, і відповідно на пошук нових підходів до підготовки майбутнього фахівця.
\end{abstract}

Ключові слова: сучасний фахівець дошкільної освіти, методологічні підходи, система вимог до вихователя.

Постановка проблеми. Сучасні соціально-економічні умови ставлять перед системою професійної освіти ставлять завдання підготовки компетентного, конкурентоспроможного фахівця для роботи в динамічно мінливих умовах, здатного самостійно i творчо вирішувати професійні завдання, готового до подальшої самоосвіти і саморозвитку. Розв'язання цієї проблеми зосереджено в побудові нового освітнього простору та реалізації положень Болонської декларації. В умовах інноваційних перетворень освітньої сфери змінюється стратегія підготовки фахівців, у тому числі й майбутніх педагогів дошкільної освіти. Особлива увага сучасних дослідників зосереджена на підготовці фахівців, здатних творчо реалізовувати власні педагогічні вміння в нових умовах життя, у ситуаціях швидких змін. У зв'язку з цим у сучасній вітчизняній педагогіці відбуваються суперечливі процеси, пов'язані зі зміною іiї змістових характеристик. Одна з відмінних особливостей цих процесів полягає в тому, що здійснюється перегляд і переосмислення змісту професійної готовності 
випускників педагогічного закладу вищої освіти в цілому і педагога дошкільної освіти зокрема.

Пошук шляхів розв'язання цієї проблеми вимагає теоретичного обгрунтування, розробки та реалізації системи вимог до вихователя в умовах компетентнісного, особистісного та діяльнісного підходів.

Аналіз останніх досліджень 3 проблеми. Теоретичне обгрунтування системи вимог до вихователя базується на концептуальних засадах освітніх інновацій, що розглядаються в соціально-філософському контексті глобальних проблем сучасності, становлення нової національної освітньої парадигми, пошуку шляхів подолання освітньої кризи (В. Андрущенко, Ж. Аллак, І. Бестужев-Лада, А. Герасимчук,

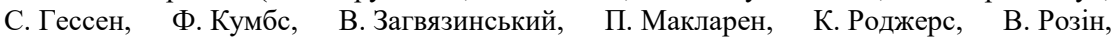
М. Романенко, Б. Саймон, П. Саух, П. Фрейре та ін.); узагальненні наукових розвідок щодо розвитку теоретичної та практичної складової інноваційних процесів у навчальних закладах України (О. Адаменко, І. Аносова, В. Землянська, О. Марущенко, О. Попова, Н. Сафонова, В. Кремень та ін.); розумінні аналізу особистісних характеристик суб'єктів інноваційної діяльності (В. Аношкіна, Г. Герасимов, Л. Ілюхіна, С. Міллер, С. Рєзванов, Е. Роджерс, Поль А. Хебіг, С. Янголовський та ін.).

Метою статті $\epsilon$ розкриття вимог до сучасного фахівця дошкільної освіти у площині трьох підходів: особистісного, діяльнісного, компетентнісного.

Виклад основного матеріалу дослідження. Розуміння того, що основним носієм та ініціатором інноваційних змін у системі дошкільної освіти $\epsilon$, насамперед, вихователь, передбачає розгляд вимог до нього у площині трьох підходів: особистісного, діяльнісного, компетентнісного. Ми визнали за доцільне умовно розділити існуючі дослідження в галузі педагогічної інноватики відповідно до зазначених підходів.

Особистісний підхід передбачає вивчення особистісних якостей педагога (інноваційну спрямованість, інноваційну культуру i т.п.), розвиток його методологічної і методичної готовності до створення, сприйняття та реалізації інновацій.

У руслі цього підходу розкриваються ціннісні орієнтації вихователя як установки особистості, що віддзеркалюють іiі фундаментальні інтереси, визначають стратегічну спрямованість професійної діяльності, становлять основу смислової сфери особистості. Цей рівень є важливим для розуміння взаємодії особистісного й професійного у педагога, оскільки абстрактна мета освіти, переломлюючись крізь смислову сферу вихователя, перетворюється в завдання педагогічної діяльності.

Засадничими для нашого дослідження $\epsilon$ такі дефініції: «інноваційна спрямованість», «готовність до інноваційної діяльності», «інноваційна культура». Ці поняття, з одного боку, найбільш повно й точно відображають погляди науковців на роль особистості в процесі становлення вихователя інноваційного типу, а, з іншого боку, вони є своєрідними маркерами відповідності системі вимог до вихователя в контексті інноваційної трансформації освіти.

Сучасні дослідники розглядають інноваційну спрямованість особистості педагога як стійку націленість особистості, яка проявляється в прогресивних мотивах, цінностях, властивостях і якостях особистості, у нових способах об'єктивації особистості в професійній, суспільній діяльності, у міжсуб'єктних відносинах, що визначає ії індивідуалізацію.

Ядром інноваційної спрямованості особистості педагога можна вважати продуктивну самосвідомість, що передбачає: усвідомлення власної самостійності, самобутності особистості; сукупність уявлень, оцінок про інноваційний потенціал власної особистості й суспільства; усвідомлення цілісності, гармонійності власної інноваційності; динамічність і безперервність процесу власного саморозвитку як творця. 
До функцій інноваційної спрямованості особистості вихователя ми відносимо: орієнтаційну (є орієнтиром у професійній діяльності); мотиваційну (являє собою вищий рівень націленості, інтересу); цілепокладання (що задає цільові орієнтири його професійної діяльності); оцінну (критерій вибору особистістю певного предмета або ставлення 3 наявних альтернатив); соціокультурну (впливає на різні сторони соціокультурного життя).

Через реалізацію зазначених функцій інноваційна спрямованість педагога певним чином впливає на самореалізацію вихователя у професійній діяльності й життєдіяльності в цілому й визначає їі успішність.

Під інноваційною спрямованістю вихователя ми розуміємо смислоутворювальну складову його особистості. Інноваційна спрямованість $є$ тенденцією, що зумовлює стиль життєдіяльності педагога. В іiі основі лежить інноваційне ставлення до світу, особистісна цілеспрямованість на пошук нового, усвідомлення обмеженості стереотипних підходів до розвитку сучасних дітей дошкільного віку.

Для обгрунтування системи вимог до вихователя важливими є дослідження вчених, що характеризують категорію «інноваційна культура» як принципово новий підхід до життєдіяльності інноваційної особистості.

Досліджуючи інноваційну культуру вчителя, В. Фокіна підкреслює, що інноваційна культура - це знання, уміння й досвід цілеспрямованої підготовки та комплексного впровадження й усебічного освоєння нового в різних галузях людської життєдіяльності при збереженні в інноваційній системі динамічної єдності старого, сучасного й нового; іншими словами - це вільне творіння нового 3 дотриманням принципу спадкоємності (Фокіна, 2001, с. 42).

За визначенням І. Циркуна, інноваційна культура - система, що включає всю сукупність нормативів (аксіологічних, гносеологічних, перетворювальних i управлінських), які детермінують якість інноваційної діяльності, і виконує такі функції: раціонально-праксіологічну, організаційно-впорядковувальну, описовопояснювальну, прогностично-управлінську, евристико-пізнавальну та комунікативнотрансляційну (Циркун, 1998, с. 9).

Інноваційна культура вихователя дошкільного закладут визначаєтсья нами як система освоєних особистістю педагогічних засобів, що забезпечують інноваційний спосіб діяльності, системоутворюючим елементом якої $є$ цінності інноваційного плану.

За нашим переконанням, інноваційна культура вихователя дошкільного закладу $є$ частиною інноваційної культури особистості й являє собою складноструктурне утворення, сукупність взаємозалежних, взаємообумовлених і взаємодоповнюючих компонентів, що забезпечують високий рівень готовності до прийняття або створення й наступної реалізації педагогічних інновацій у процесі професійної діяльності (Дичківська, 2017).

Центральним компонентом інноваційної культури вихователя дошкільного закладу $\epsilon$ методологічна культура, яка являє собою особливий склад мислення, заснований на знанні методологічних норм і вмінь їх застосовувати в процесі вирішення проблемних педагогічних ситуацій.

Методологічна культура має у своїй структурі три складові:

- інформаційну (знання про досягнення сучасної педагогічної науки, сутність інноваційної діяльності педагогів, призначення й структуру психолого-педагогічного дослідження та організацію дослідно-експериментальної роботи в умовах освітньої установи);

- операціональну (уміння педагога, пов'язані 3 одержанням і переробкою професійно значущої інформації; виділенням i формулюванням педагогічної проблеми, визначенням варіантів їі розв'язку і їхньою наступною перевіркою; проектуванням освітнього процесу; здійсненням рефлексії професійно-педагогічної діяльності.); 
- мотиваційну (сукупність установок педагога, що проявляються в критичному ставленні до педагогічних явищ; у перетворенні педагогічної практики відповідно до ціннісних орієнтирів розвитку системи освіти).

Другим за значущістю компонентом інноваційної культури педагога закладу дошкільної освіти $\epsilon$ інформаційна культура.

Інформаційна культура розглядаються як «сукупність інформаційного світогляду й системи знань, умінь, що забезпечують цілеспрямовану самостійну діяльність 3 оптимального задоволення індивідуальних інформаційних потреб з використанням як традиційних, так і нових інформаційних технологій» (Гендіна, 2003). Серед критеріїв сформованості інформаційної культури у вихователя дошкільного закладу автор визначає: наявність постійних інформаційних потреб у педагога; знання про способи (джерела) одержання й використання необхідної інформації; сформованість у педагога вміння використовувати персональний комп'ютер у професійній діяльності; сформованість у педагога вміння ефективно використовувати різні комунікативні можливості; володіння аналізом і синтезом отриманої педагогічної інформації.

Третім компонентом інноваційної культури педагога дошкільного закладу, на думку дослідниці, $є$ безпосередньо інноваційна діяльність як мотивований, цілеспрямований i усвідомлений процес створення, освоєння, впровадження й поширення сучасних ідей (теорій, технологій, методик і т.п.), актуальних і адаптованих для певних умов відповідно до прийнятих критеріїв.

Для визначення системи вимог вважаємо за необхідне детально схарактеризувати структуру інноваційної діяльності вихователя.

В основу нашого розуміння структури інноваційної діяльності вихователя покладено наукові розвідки О. Леонтьєва, який до компонентів діяльності відніс наступні: потребу, мотив, мету, умови, дії й концепцію навчальної діяльності Д. Ельконіна, В. Давидова. Саме ці вчені обов'язковими структурними компонентами діяльності вважали дії планування, контролю, оцінки й рефлексії (Леонтьєв, 2004; Ельконін, 1989; Давидов, 1972).

Розгортання інноваційної діяльності вихователя відбувається, на наш погляд, таким чином: відчуття вихователем потреби у здійсненні інновацій, яку він усвідомлює як мотив діяльності; формулювання мети діяльності щодо впровадження інновацій; аналіз умов, в яких має здійснюватися досягнення мети (мета й аналіз умов iii досягнення складають задачу діяльності); планування дій для досягнення мети, що включають експериментальну складову; система дій, що здійснюються відповідно до плану; прогностичний та діагностичний контроль дій та оцінка результату; рефлексія здійснених способів дій; постановка наступної задачі інноваційної діяльності.

При такому розумінні структури інноваційної діяльності вихователя на передній план виходить поняття суб'єкта діяльності як суб'єкта інновацій.

Суб'єкт (лат. subjektum - той, що знаходиться в основі) - категорія філософії і психології, що позначає протистояння людини й світу та виділяє в їх взаємодії регулюючу, керуючу, авторську першооснову людини.

А. Пригожин відзначає, що головна характеристика суб'єкта інновацій - це його діяльнісна самосвідомість, тобто розуміння своєї особистої ініціативи як суб'єктивно можливої й суспільно прийнятої основи власного існування. Автор представляє суб'єктність як єдність цілепокладання й цілездійснення в одній особі. Суб'єкт є діячем, здатним до вибору типу діяльності, конкретної ролі для себе серед інших суб'єктів, до визначення власних цілей і засобів для їхнього досягнення. Одночасно суб'єкт є носієм і автором внеску в будь-яку спільну діяльність, партнером у міжсуб'єктних відносинах (Пригожин, 1989).

Такий підхід має особливе значення для нашого дослідження, оскільки становлення дитини-дошкільника як суб'єкта життєдіяльності є сьогодні одним 3 пріоритетних завдань дошкільної освіти. 
Ціннісна свідомість формується в дитини тоді, коли вихователь бачить у ній принципово рівного собі, вільного у виборі цінностей і психологічно унікального суб'єкта, з яким він, старший і більш досвідчений та мудрий, прагне поділитися своїми цінностями, аби вони стали загальними для них, тобто, увібрали в себе й особливості духовної позиції вихованця; у цьому змісті говорять, що виховує не тільки учитель учня, але й учень учителя. Але це й означає, що виховання є одночасно й спілкування, і творчість, а не комунікація, не управління й не обслуговування.

Діяльнісно-суб'єктний підхід до розуміння інноваційної діяльності вихователя уможливлює більш багатомірно побачити взаємодію педагогів у цьому процесі. Як відзначають В. Сластьонін і Л. Подимова, педагог, як суб'єкт інноваційної діяльності та іiі організатор, вступає у взаємодію з іншими членами педагогічного співтовариства в процесі створення, використання і розповсюдження новації. Він обговорює зміст нововведення і ті зміни, які можуть відбутися в предметах, свідомості, звичаях, традиціях. Інноваційну діяльність вихователів можна розглядати як взаємодію суб'єктів інноваційного процесу, яка спрямована на створення й реалізацію нововведень у цілях, змісті і способах педагогічної діяльності. Водночас саме взаємодія реалізує рух інноваційної системи та актуалізує зв'язок їі складових (Сластьонін, Подимова, 1997).

На наш погляд, категорію «суб'єкт інноваційної педагогічної діяльності» необхідно розглядати як системоутворюючу при аналізі інноваційних процесів в освітянській галузі.

Важливим для розуміння системи вимог до вихователя в умовах інноваційної трансформації освіти $є$ компетентнісний підхід. У процесі переломлення професійного досвіду через особистість вихователя, інтеграції іiї ціннісно-смислової й діяльнісної основи відбувається становлення професійно-педагогічної компетентності.

Усвідомлення вихователем інноваційної діяльності як цінності значною мірою залежить від наявності у нього інноваційної компетентності.

Взаємозв'язок інноваційної компетентності й здатності вихователя до здійснення інноваційної діяльності сприяє зростанню інтересу науковців до вивчення феномену інноваційної компетентності педагога (Н. Ільїна, Н. Клокар, Л. Петриченко, А. Хуторськой та ін.).

I. Коновальчук переконує, що інноваційна компетентність педагога - це інтегративна властивість особистості, яка є результатом синтезу базової професійної підготовки й практичного професійного й особистісного соціально-психологічного досвіду. Науковець розглядає інноваційну компетентність як складову загальної професійно-педагогічної компетентності, зміст якої зумовлюється особливостями інноваційної діяльності, її суспільною значимістю, творчим, суб'єктним характером та спрямованістю на неперервне творення нового, розвитку особистісного й професійного потенціалу педагога (Коновальчук, 2015).

О. Артамонова під інноваційною компетентністю педагога розуміє досягнення ним певного рівня особистісного й професійного прояву майстерності в його інноваційній діяльності (Артамонова, 2013).

Ми визначаємо інноваційну компетентність як показник готовності до впровадження сучасних технологій дошкільної освіти й виокремлюємо в іії структурі такі компоненти: поінформованість про інноваційні педагогічні технології, належне володіння їх змістом і методикою, високу культуру використання інновацій у навчально-виховній роботі, особисту переконаність у необхідності застосування інноваційних педагогічних технологій (Дичківська, 2010).

Здійснений теоретичний аналіз існуючих вітчизняних та зарубіжних наукових досліджень у галузі педагогічної інноватики згідно з особистісним, діяльнісним, компетентнісним підходами дає можливість обгрунтувати розроблену нами систему вимог до вихователя в контексті інноваційної трансформації освіти. 
Тож з огляду на означенні підходи, можемо стверджувати, що система складається 3 трьох структурних компонентів: особистісного, діяльнісного й компетентнісного.

Особистісний компонент системи вимог містить три складових: інноваційну спрямованість, готовність до інноваційної професійної діяльності, інноваційну культуру вихователя.

Інноваційна спрямованість передбачає наявність у вихователя інноваційного ставлення до світу; особистісної цілеспрямованості на пошук нового; активного пошуку нових технологій розвитку дітей дошкільного віку, впровадження чужого досвіду й створення власних форм, прийомів, методів роботи 3 дошкільниками; усвідомлення обмеженості стереотипних підходів до розвитку сучасних дітей дошкільного віку.

Показниками готовності вихователя до інноваційної професійної діяльності $\epsilon$ мотиваційно-ціннісне ставлення до професійної діяльності; змістовне знання про нові наукові й новаторські підходи до педагогічного процесу дошкільного закладу; уміння аналізувати зміни в освітній діяльності, розвитку особистісних якостей дошкільників.

На нашу думку, про сформованість у вихователя інноваційної культури будуть свідчити: здатність формулювати освітні цілі на підставі аналізу сучасних наукових даних про закономірності розвитку дошкільників й актуальних запитів суспільства; усвідомлення доцільності й ефективності власних інноваційних пошуків; володіння педагогічними засобами, що забезпечують інноваційний спосіб діяльності.

Суть вимог, що є змістом діяльнісного компонента системи, розкривається через розуміння структури інноваційної діяльності вихователя, яку ми запропонували вище, й суб'єкта цієї діяльності. Вимогами до педагога згідно зі структурними елементами інноваційної діяльності $є$ : відчуття вихователем потреби у здійсненні інновацій, яку він усвідомлюе як мотив діяльності; формулювання мети діяльності стосовно впровадження інновацій; аналіз умов, в яких має здійснюватися досягнення мети; планування дій для досягнення мети, що включають експериментальну складову; система дій, що здійснюються відповідно до плану; прогностичний та діагностичний контроль дій та оцінка результату; рефлексія здійснених способів дій.

Відчуття вихователем потреби у здійсненні інновацій, яку він усвідомлює як мотив діяльності, забезпечує мотиваційно-ціннісне ставлення до інноваційної діяльності.

Невід'ємною вимогою до вихователя в контексті нашого розуміння суб'єкта діяльності є усвідомлення своєї особистої ініціативи як суб'єктивно можливої й суспільно прийнятої основи власного існування й ставлення до дитини як до суб'єкта діяльності й спілкування, прийняття її суб'єктності як цінності, здійснення взаємодії 3 нею на суб'єкт-суб' єктній основі, створення умов для становлення ії особистості як вільної, відповідальної, творчої.

Важливою характерною ознакою вихователя, здатного здійснювати інноваційну діяльність, $\epsilon$ його схильність до конструктивної взаємодії 3 іншими членами педагогічного співтовариства, 3 батьками вихованців у процесі створення, використання і розповсюдження новацій на суб'єктній основі, оскільки саме взаємодія реалізує рух інноваційної системи та актуалізує зв'язок ії складових.

Отже, окрім вимог до вихователя, які обумовлені структурою інноваційної діяльності, діяльнісний компонент розробленої нами системи містить: розуміння дитини як суб'єкта діяльності й спілкування, прийняття іiі суб'єктності як цінності, здійснення взаємодії з нею на суб'єкт-суб'єктній основі, створення умов для становлення іiї особистості як вільної, відповідальної, творчої; здатність до взаємодії $з$ іншими членами педагогічного співтовариства, батьками вихованців у процесі створення, використання і розповсюдження новацій на суб'єктній основі.

Компетентнісний компонент розробленої нами системи вимог до вихователя в контексті інноваційної трансформації освіти передбачає наявність у нього інноваційної компетентності, яка проявляється у таких аспектах: умінні складати нові програми актуалізації й розвитку здібностей дітей раннього й дошкільного віку; здатності 
вихователя передбачати результати впровадження інноваційних технологій; нестереотипності сприйняття; готовності до творчої самореалізації, саморозвитку протягом життя.

Висновки i перспективи подальших розвідок. В інноваційних освітніх перетвореннях особливо високими $є$ вимоги до рівня теоретичних знань і практичної підготовки вихователя. Вихователь повинен уміти спрямовувати навчально-виховний процес на особистість вихованця, вибудовувати свою професійну діяльність так, щоб кожна дитина мала необмежені можливості для самостійного і високоефективного розвитку. А це у принципово інших вимірах визначає проблематику i зміст професійної та особистісної підготовки вихователя, актуалізує необхідність створення педагогічних систем, зорієнтованих на інноваційну діяльність, і відповідно на пошук нових підходів до підготовки майбутнього фахівця.

Перспективним може бути вивчення потенційних можливостей неформальної та інформальної освіти в забезпеченні підготовки майбутніх вихователів закладів дошкільної освіти, розроблення ціннісних засад педагогічної діяльності майбутніх вихователів закладів дошкільної освіти у контексті євроінтеграційних процесів у сучасному освітньому просторі.

\section{СПИСОК ВИКОРИСТАНИХ ДЖЕРЕЛ}

Фокина, В. (2001). Инновационная культура преподавателя ВУЗа: теоретическая модель социологического исследования. Инновации в образовании. № 1. С. 38-55.

Цыркун, И. (1998). Дидактические основы генезиса специальной инновационной подготовки студентов в условиях многоуровневого образования. Доктор педагогических наук. Минск. 32 с.

Дичківська, I. (2017). Підготовка майбутніх вихователів дошкільних закладів до інноваційної педагогічної діяльності: теорія і методика: монографія. Рівне: Видавець О. Зень. 372 с.

Гендина, Н. (2003). Информационная грамотность или информационная культура: альтернатива или единство. Школьная библиотека. № . С. 8-14.

Леонтьев, А. (2004). Деятельность. Сознание. Личность. Москва: Смысл, Академия. 346 с.

Эльконин, Д. (1989). Избранные психологические труды / под ред. В. В. Давыдова, В. П. Зинченко. Москва: Педагогика. 560 с.

Давыдов, В. (1972). Виды обобщения в обучении. Москва: Педагогика. 1972. 423 с.

Пригожин, А. (1989). Нововведения: стимуль и препятствия (сочииальные проблемы инноватики). Москва : Политиздат. $271 \mathrm{c}$.

Сластенин, В., Подымова, Л. (1997). Педагогика: инновационная деятельность. Москва: ИЧП «Изд-во Магистр», 1997. 308 с.

Коновальчук, І. (2015). Теоретичні та технологічні засади реалізачії інновацій у загальноосвітніх навчальних закладах. Доктор педагогических наук. Житомирський держ. ун-т ім. I. Франка. Житомир. 437 с.

Артамонова, Е. (2013). Формирование инновационной компетентности педагога в процессе обучения в вузе. Педагогическое образование и наука. № 5. С. 17-26.

Дичківська, I. (2010). Інноваційна компетентність педагога. Дошкільне виховання. № 1. C. 7-11.

\section{REFERENCES}

Fokina, V. (2001). Innovatsionnaya kultura prepodavatelya VUZa: teoreticheskaya model sotsiologicheskogo issledovaniya [The Innovative Culture of a University Teacher: a Theoretical Model of Sociological Research]. Innovatsii v obrazovanii. No 1. S. 38-55. (in Russian)

Tsyrkun, I. (1998). Didakticheskiye osnovy genezisa spetsialnoy innovatsionnoy podgotovki studentov $v$ usloviyakh mnogourovnevogo obrazovaniya. [Didactic Foundations 
of the Genesis of Special Innovative Student Training in Multilevel Education]. Doctor pedagogicheskikh nauk. Minsk. 32 s. (in Russian)

Dychkivska, I. (2017). Pidhotovka maibutnikh vykhovateliv doshkilnykh zakladiv do innovatsiinoi pedahohichnoi diialnosti: teoriia i metodyka. [Preparation of Future Preschool Teachers for Innovative Pedagogical Activity: Theory and Methodology]: monohrafiia. Rivne: Vydavets O. Zen. 372 s. (in Ukrainian)

Gendina, N. (2003). Informatsyonnaya gramotnost ili informatsionnaya kultura: alternativa ili edinstvo [Information Literacy or Information Culture: Alternative or Unity]. Shkolnaya biblioteka. No 3. S. 8-14. (in Russian)

Leontyev, A. (2004). Deyatelnost. Soznaniye. Lichnost. [Activity. Consciousness. Personality]. Moskva: Smysl. Akademiya. 346 s. (in Russian)

Elkonin, D. (1989). Izbrannyye psikhologicheskiye trudy. [Selected Psychological Works] / pod red. V. V. Davydova \& V. P. Zinchenko. Moskva: Pedagogika. 560 s. (in Russian)

Davydov, V. (1972). Vidy obobshcheniya $v$ obuchenii [Types of Generalization in Learning.]. Moskva: Pedagogika. 423 s. (in Russian)

Prigozhin, A. (1989). Novovvedeniya: stimuly i prepyatstviya (sotsialnyye problemy innovatiki) [Innovations: Incentives and Obstacles (Social Problems of Innovation)]. Moskva : Politizdat. 271 s. (in Russian)

Slastenin, V., Podymova, L. (1997). Pedagogika: innovatsionnaya deyatelnost [Pedagogy: Innovative Activity]. Moskva: IChP "Izd-vo Magistr". 308 s. (in Russian)

Konovalchuk, I. (2015). Teoretychni ta tekhnolohichni zasady realizatsii innovatsii u zahalnoosvitnikh navchalnykh zakladakh [Theoretical and Technological Principles of Innovation Implementation in Secondary Schools]. Doctor pedahohichnykh nauk. Zhytomyrskyi derzh. un-t im. I. Franka. Zhytomyr. 437 s. (in Ukrainian)

Artamonova, E. (2013). Formirovaniye innovatsionnoy kompetentnosti pedagoga v protsesse obucheniya $\mathrm{v}$ vuze. [Formation of Innovative Competence of a Teacher in the Process of Learning at a University]. Pedagogicheskoye obrazovaniye i nauka. No 5. C. 1726. (in Russian)

Dychkivska, I. (2010). Innovatsiina kompetentnist pedahoha [Teacher's Innovative Competence]. Doshkilne vykhovannia. 2010. No1. S. 7-11. (in Ukrainian).

\title{
METHODOLOGICAL APPROACHES IN CONSTRUCTION THE SYSTEM OF REQUIREMENTS FOR THE MODERN SPECIALIST OF PRESCHOOL EDUCATION
}

\author{
Ilona Dychkivska \\ Doctor of Sciences (in Pedagogy), \\ Professor, Head at the Department of Pedagogy \\ and Psychology (Preschool and Correctional) \\ named after Professor T.Ponimanska, \\ Rivne State University for the Humanities, \\ Rivne, Ukraine \\ ORCID: 0000-0002-9353-5666 \\ e-mail: ilonardgu@gmail.com
}

\begin{abstract}
The article deals with the analysis of the change in the strategy of training modern specialists, including preschool teachers, in the conditions of innovative transformation of the educational sphere. The concepts "innovative orientation of the preschool teachers", "readiness to innovation", "innovative culture", "innovative competence" and links between them are described. Particular attention of modern researchers is focused on the training of specialists who are able to creatively implement their own pedagogical skills in new conditions of life, in situations of rapid change. Analysis of
\end{abstract}


the approaches of different authors shows that there is no single point of view in understanding their essence. However, scientists note the importance of the role of the teacher in the implementation of innovative processes, which actualizes the problem of understanding the requirements for it. The article substantiates and develops a set of requirements for educators in the context of implementation of innovations in preschool education in the plane of three approaches: personal (presence of innovative orientation, formation of innovative culture), activity (ownership of technologies of research and project work, acceptance of the subject interaction with other educators) and competency (mastering innovative competence). Analyzing the requirements for the level of theoretical knowledge and practical training of the teacher, it has been emphasized that he should be able to direct the educational process on the personality of the pupil, to build their professional activity so that each child has unlimited opportunities for independent and highly effective development. This, in fundamentally different dimensions, defines the problems and content of the professional and personal training of the tutor, actualizes the need to create pedagogical systems oriented to innovation, and accordingly to search for new approaches to training the future specialist.

Keywords: modern specialist of preschool education, methodological approaches, system of requirements for the preschool teacher.

Стаття надійшла до редакиії 01.10.2019 p. 